\title{
RECONCILIATION IN TRANSLATION: INDIGENOUS LEGAL TRADITIONS AND CANADA'S TRUTH AND RECONCILIATION COMMISSION
}

\author{
Kirsten Anker*
}

One of the key elements of reconciliation identified in the recent final report of the Truth and Reconciliation Commission of Canada [TRC] is the revitalization of Indigenous law and legal traditions. Indeed, the practices of the TRC itself have attempted to embody this principle. However, a concern about state-sponsored reconciliation is that the recognition of Indigenous legal traditions is an empty gesture without a robust engagement with them. This article offers one possible method for outsiders to engage with Indigenous traditions in a way that goes beyond lip service and beyond the limitations of superficial forms of recognition in which equivalence is too quickly assumed. By paying attention to the ways that Indigenous principles and practices are embedded in a network of ideas about the world, a picture of a whole "legal sensibility" emerges that, through comparison, shows the dominant legal sensibility to be one alternative among many. In this way, reconciliation is approached as a process of "unsettling" what is taken for for granted in mainstream understandings of reconciliation and law.

Un des principaux éléments de la réconciliation établis dans le récent rapport final de la Commission de vérité et réconciliation du Canada [CVR] est la revitalisation du droit autochtone et des traditions juridiques autochtones. À vrai dire, la CVR elle-même a tenté d'intégrer ce principe dans ses pratiques. Cependant, une des craintes relatives à la réconciliation chapeautée par l'Etat est que la reconnaissance des traditions juridiques autochtones soit un geste vain si elle n'est pas accompagnée d'un engagement ferme. Dans cet article, l'auteure présente un moyen possible de permettre aux profanes d'intégrer les traditions autochtones en dépassant les væux pieux et les limites des formes superficielles de reconnaissance dans lesquelles l'équivalence est trop vite supposée. Lorsqu'on est attentif aux façons dont on intègre les principes et pratiques autochtones à une conception du monde, l'image d'une " sensibilité juridique » tout entière se dégage qui, par la comparaison, montre que la sensibilité juridique dominante n'est qu'une sensibilité parmi de nombreuses autres. Ainsi, la réconciliation est abordée comme une démarche consistant à " décoloniser " ce qui est tenu pour acquis dans la conception habituelle de la réconciliation et du droit.

\footnotetext{
Associate Professor, Faculty of Law, McGill University. This article is drawn from an article commissioned by the Truth and Reconciliation Commission in 2012. I wish to thank Charlotte Burns, Tina Hlimi, Jessica Labranche Hamellin, Josh Mentanko, and Neesha Rao for their helpful research assistance in preparing this article. Any errors remain my own.
} 


\section{INTRODUCTION}

One of the key elements of reconciliation identified in the recent final report of the Truth and Reconciliation Commission of Canada [TRC] is the revitalization of Indigenous ${ }^{1}$ law and legal traditions. ${ }^{2}$ Respect for these traditions had also been built into the practices of the TRC itself, for example, in providing "culturally appropriate" spaces for Indian residential school [IRS] survivor testimony, in the use of honorary witnesses of truth and reconciliation events, and in what is referred to as the "Aboriginal principle of witnessing." 3 While witnessing is a concept familiar enough in the business of truth and reconciliation commissions, clearly its importance as an "Aboriginal principle" to this particular truth and reconciliation commission is that it seeks to address the attempt, through residential schools, to eradicate Indigenous law, languages, and cultures. This article argues that the incorporation of Indigenous principles requires that the process of understanding their significance take place via a practice of cross-cultural translation that also puts conventional non-Indigenous understandings of reconciliation under the microscope. The larger argument is that reconciliation in Canada involves building better relationships, not as a form of national unity but, rather, by striving for decolonization via what has been called the "unsettling" of accepted myths, narratives, and ideals that remain, at their heart, colonial in nature."

Given that the historical policies of assimilation aimed at the destruction of Indigenous languages and culture were based on a brute lack of respect for Indigenous law and sovereignty, it is fitting to consider that state-sponsored reconciliation must include a genuine engagement with Indigenous legal traditions. This is why Indigenous scholars such as John Borrows, Val Napoleon, and Taiaiake Alfred argue that reconciliation needs to include a rethinking of Aboriginal rights - and perhaps Canadian constitutionalism itself - in a way that is more robustly cognizant of Indigenous law-making. ${ }^{5}$ To do otherwise runs the risk that gestures of respect for culture alone are nothing more than platitudes and empty symbolism. ${ }^{6}$ While Indigenous legal traditions have been recognized in some, limited, ways in Canada, their treatment by

1 This article uses the term Indigenous to refer collectively to the peoples whose ancestors lived on Turtle Island/North America prior to colonization and, where possible, uses the name people call themselves in their own languages.

"Aboriginal" or "Indian" are used in the context of state law or policy in which these terms are still current.

2 See Truth and Reconciliation Commission Canada (TRC), Honoring the Truth, Reconciling for the Future: Summary of the Final Report of the Truth and Reconciliation Commission of Canada (Ottawa: TRC, 2015) at 16 and Calls to Action $27,28,45$ and 50.

3 Indian Residential Schools Agreement, "Schedule N: The Mandate for the Truth and Reconciliation Commission of Canada" at para 1, online: TRC <www.trc.ca/websites/trcinstitution/index.php? $=7>$.

4 See Paulette Regan, Unsettling the Settler Within: Indian Residential Schools, Truth Telling, and Reconciliation in Canada (Vancouver: UBC Press, 2010) at 11-12, 33-34ff.

5 John Borrows, Recovering Canada: The Resurgence of Indigenous Law (Toronto: University of Toronto Press, 2002); Val Napoleon, "Reconciliation for the Gitxsan: Who Gets to Say What Happened?" in Catherine Bell \& David Kahane, eds, Intercultural Dispute Resolution in Aboriginal Contexts (Vancouver: UBC Press, 2004) 176 [Napoleon, "Reconciliation"]; Taiaiake Alfred, Wasáse : Indigenous Pathways of Action and Freedom (Toronto: University of Toronto Press, 2005). See also Minnawaanagogiizhigook (Dawnis Kennedy), "Reconciliation without Respect? Section 35 and Indigenous Legal Orders" in Law Commission of Canada, ed, Indigenous Legal Traditions, (Vancouver: UBC Press, 2007).

6 Napoleon, "Reconciliation," supra note 5; Jeff Corntassel \& Cindy Holder, "Who’s Sorry Now? Government Apologies, Truth Commissions, and Indigenous Self-Determination in Australia, Canada, Guatemala, and Peru" (2008) 9:4 Human Rights Rev 465 at 486. 
Canadian state law remains ambiguous. Are they merely facts of life in Indigenous communities, aids in proving historic practices or the occupation of land, sources of Aboriginal rights, part of the constitutional fabric of Canada, or emanations of Indigenous self-government? The answer will shape the kind of role that Indigenous legal traditions can play in the reconciliation project.

The Supreme Court of Canada has stated that an understanding of Aboriginal rights should take into account both common law and Aboriginal perspectives, ${ }^{7}$ and it has referred to Aboriginal rights as an "intersocietal law." 8 This characterization hints at an idea of justice that requires dialogue, mutual recognition, and respect, ${ }^{9}$ but the Court does not explicitly engage with this idea of justice, elaborate what it means to take into account different perspectives, or struggle with the particular languages and ways of life through which Indigenous legal traditions are lived. Further, some critics are concerned that the process of "taking into account" is unidirectional rather than mutual - something that is implicit in the way Chief Justice Beverley McLachlin has described the reconciliation of perspectives: Aboriginal practices must be translated into a common law right. ${ }^{10}$

For many, alternative or restorative justice processes, such as the TRC, offer the possibility of a more respectful inclusion of Indigenous practices and philosophies or directly reflect them. ${ }^{11}$ The assumption that any given process does so has to be approached with caution, however. As the critical literature on restorative justice suggests, "reconciliation" and "truth" as the path to a peaceful community have as much European baggage - such as the harmony model or confessional practices of Christian traditions ${ }^{12}$ - as the adversarial litigation process. Instead, recognition of, and respect for, Indigenous legal traditions have to come via what Cree/Nêhiyawahk scholar Willie Ermine calls an "ethical space" - that is, a space in between different "thought worlds" in which engagement is "modeled on appropriate, ethical and human principles" and in which parties collectively observe the way that "unnoticed cultural differences can clash without our realizing what is occurring." ${ }^{.13}$ The space of engagement is thus potentially an uncomfortable one, with "our" grounds always unsettled and called into question. In this view, it is not enough for the TRC, for example, to strive simply for "relational," rather than "cheap," reconciliation, without also opening up the idea of reconciliation itself to engagement with Indigenous languages and traditions.

This article proposes to investigate a modest number of the resources offered by the great variety of Indigenous traditions in Canada with a view to rethinking "reconciliation." The goal of the exercise is not to find neat equivalents as translations - to take at face value, for instance, the Haudenosaunee Great Law of Peace as an exercise in political reconciliation in bringing warring communities into a peaceful

\footnotetext{
Delgamuukw v British Columbia, [1997] 3 SCR 1010 at para 81 [Delgamuukw].

$R v$ Van der Peet, [1996] 2 SCR 507 at para 42, 137 DLR (4th) 289 [Van der Peet].

9 See generally James Tully, Strange Multiplicity: Constitutionalism in an Age of Diversity (Cambridge: Cambridge University Press, 1995).

$10 R$ v Marshall; $R$ v Bernard, [2005] 2 SCR 220, 255 DLR (4th) 1 [Marshall; Bernard].

11 Declan Roche, "Dimensions of Restorative Justice" (2006) 62:2 J Soc Issues 217 at 51; R v Gladue, [1999] 1 SCR 688 at para 70 .

12 Laura Nader, Harmony Ideology: Justice and Control in a Zapotec Mountain Village (Stanford: Stanford University Press, 1990); Tim Kelsall, "Truth, Lies, Ritual: Preliminary Reflections on the Truth and Reconciliation Commission in Sierra Leone" (2005) 27:2 Human Rights Q 361; Morgan Brigg, "Mediation, Power, and Cultural Difference" (2003) 20:3 Conflict Resolution Quarterly 287.

13 Willie Ermine, "Ethical Space of Engagement” (2007) 6:1 Indigenous LJ 193 at 194, 202-203.
} 
federation ${ }^{14}$ - but, rather, to engage in a hermeneutic process ${ }^{15}$ that will reflect back on the English terms, attending to the ways in which culturally located words and practices are brought to the fore in the to-andfro processes of translation, explanation, representation, and interpretation that comparison entails. Thus, recognizing Canada's multi-juridical legal culture ${ }^{16}$ in the context of the TRC involves not simply imagining the contribution of Indigenous law to processes already set and framed by a particular understanding of reconciliation but also requires having inter-cultural conversations from the ground up. The second part of the article will frame the argument for why and how Indigenous understandings of law, sovereignty, and reconciliation should be part of state responses to residential schools. Its two sections canvass, first, the ways in which the policy and practice of the schools constituted harms against Indigenous languages and cultures and, more fundamentally, an infringement of Indigenous sovereignty or right to self-determine and, second, the place currently accorded to Indigenous traditions in the Canadian constitution and legal system. The third part then suggests a method for establishing an "ethical space" of recognition and presents three short examples as an initial elaboration of the method.

\section{REASONS FOR ROBUST ENGAGEMENT WITH INDIGENOUS LEGAL TRADITIONS}

While residential schools had the effect of crippling Indigenous languages and, through them, the broader way of life of the first peoples of Canada, it would be a mistake to see assimilation policies "merely" as an attack on culture or to understand the harm in terms of a right to language and culture alone. In international law and jurisprudence, for instance, cultural rights are understood as being interdependent, with self-determination being the ultimate collective right. Thus, while other colonial policies have targeted law and self-governance more overtly - replacing hereditary leaders with elected band councils, banning the institution of the potlatch, or interfering with matrilineal succession through women's loss of status on marrying out, for instance - the cultural genocide of residential schools constitutes a harm affecting legal traditions not just because law is also part of culture and closely tied to language but also because the assumption of control was a direct travesty of Indigenous sovereignty and self-governance under traditional legal orders. ${ }^{17}$ However, if reconciliation behooves settler law to recognize Indigenous legal orders in response, ${ }^{18}$ the current patterns in which they are translated are both superficial and imbalanced and do not approach the necessary "ethical space."

14 Mark Walters, “The Jurisprudence of Reconciliation: Aboriginal Rights in Canada” in Will Kymlicka \& Bashir Bashir, eds, The Politics of Reconciliation in Multicultural Societies (Oxford: Oxford University Press, 2008$) 170$.

15 Clifford Geertz, Local Knowledge: Further Essays in Interpretive Anthropology (New York: Basic Books, 1983 ) ch 8.

16 See John Borrows, Canada's Indigenous Constitution (Toronto: University of Toronto Press, 2010) ch 5. [Borrows, Indigenous Constitution].

17 Courtney Jung, "Canada and the Legacy of the Indian Residential Schools: Transitional Justice for Indigenous Peoples in a Non Transitional Society" in Paige Arthur, ed, Identities in Transition: Challenges for Transitional Justice in Divided Societies (Cambridge: Cambridge University Press, 2010) 241.

18 Brenda L Gunn, "Moving beyond Rhetoric: Working toward Reconciliation through Self-Determination" (2015) 38:1 Dal LJ 237 at 254. 


\section{A. Understanding the Harm: Language, Culture, and Self-Determination 1. Residential Schools}

My father was physically tortured by his teachers for speaking Tseshaht: they pushed sewing needles through his tongue, a routine punishment for language offenders. - Randy Fred ${ }^{19}$

This statement captures, in one violent image, the interest of governments and missionaries in the tongues of Indigenous peoples in Canada that has been detailed by the TRC, the Royal Commission on Aboriginal Peoples $[\mathrm{RCAP}]^{20}$ and many other historical reviews of Indian policy. Although learning Indigenous languages was key in the evangelical efforts of clergy in the earliest residential schools in New France, by the time the residential schools system expanded in the mid-1800s, schools were charged with suppressing them. ${ }^{21}$ At this time, government bureaucrats saw Indigenous peoples as an impediment to European goals in North America and, unable to engage in the wholesale removal or genocide, proposed an approach of peaceful assimilation with its centerpiece an educational policy that would consist in "the acquirements of the language, arts and customs of a civilised life" and, concomitantly, "a weaning from the habits and feelings of their ancestors. $" 22$

In the face of encroaching European settlement, the disappearance of game, and increasing difficulties for Indigenous peoples in maintaining their ways of life, some communities expressed a desire for access to schools and training and for learning English. ${ }^{23}$ However, for the government, the civilizing project was seen as nothing less than the replacement of Indigenous ontology with a European one. The government approach can be seen, as the RCAP report points out, in the role that language was to play in the residential school curriculum: children had to learn English or French because their native tongues were not apt to express core concepts of European culture and, thus, "could not carry the burden of civilization." ${ }^{24}$ Further, since civilization was only to be assured by driving a permanent wedge between parent and child, bilingualism or multilingualism would not provide a sufficiently profound rupture, and so the exclusive use of English or French was insisted upon, either by punishment or reward. As the report notes, "the entire residential school project was balanced on the proposition that the gate to assimilation was unlocked by the progressive destruction of Aboriginal languages. 25

19 Celia Haig-Brown, Resistance and Renewal: Surviving the Indian Residential School (Vancouver: Arsenal Pulp Press, 1998) at 16.

20 Indigenous and Northern Affairs Canada, Report of the Royal Commission on Aboriginal Peoples (Ottawa: Supply and Services Canada, 1996) [RCAP Report].

21 Among the reasons mooted for this shift is the removal of strategic importance of alliances with Aboriginal communities after the end of hostilities between Britain and France and the collapse of the fur trade, the reduced self-sufficiency of Aboriginal peoples faced with colonial encroachments on their lands, and the transfer of British jurisdiction with respect to "Indians" from the military to a civil bureaucracy with little historic appreciation of British-Aboriginal alliances. See JR Miller, Shingwauk's Vision: A History of Native Residential Schools (Toronto: University of Toronto Press, 1996) at $62-63$.

RCAP Report, supra note 20, volume 1: Looking Forward, Looking Back, at 351.

25 Ibid. 
As an assimilative tool, residential schools were of course only part of a broader set of policies asserting the superiority of colonial culture and consistently devaluing and undermining Indigenous ways of life, from the enfranchisement provisions of the Gradual Civilization Act (1857) to the prohibitions on the potlatch and sundance ceremonies. ${ }^{26}$ But the intuition of officials behind the suppression of languages was that Indigenous languages held the key to the survival of Indigenous lifeworlds, an assumption now supported by scholarship on the role of language in constructing meaningful reality ${ }^{27}$ and reflected in the contemporary urgency in retrieving and maintaining traditional languages. ${ }^{28}$ In addition to the conventional legally recognized harms suffered by survivors, such as physical and sexual assault, came the enormity of the loss of culture, language, and connection to family. ${ }^{29}$

\section{Damage to Culture in International Law}

While Canadian domestic law has no language in which to express these losses as a legally cognizable harm, International law instruments have articulated several cognate and relevant rights. The assumption of control over Indigenous peoples in the IRS prevented them from educating their children - sometimes from even communicating effectively with them - and, thus, from reproducing their lifeworlds as they saw fit. The TRC makes no bones about calling this cultural genocide. ${ }^{30}$ While the applicability of the international law of genocide to residential schools is debated - for instance, although the removal of children is prohibited under Article 2(e) of the 1948 Convention on the Prevention and Punishment of the Crime of Genocide [Genocide Convention], ${ }^{31}$ the destruction of the group's culture was omitted from the convention $^{32}$ - other human rights instruments provide alternative and forceful means of addressing attacks on cultural identity per se. Both the 1966 International Covenant on Civil and Political Rights

26 Christopher Bracken, The Potlatch Papers: A Colonial Case History (Chicago: University of Chicago Press, 1997); Gradual Civilization Act (1857) 20 Victoria, c. 26 (Province of Canada).

27 See Peter Berger \& Thomas Luckmann, The Social Construction of Reality: A Treatise in the Sociology of Knowledge (New York: Anchor Books, 1966); George Lakoff, Women, Fire and Dangerous Things: What Categories Reveal about the Mind (Chicago: University of Chicago Press, 1987).

28 Marianne Ignace \& Ron Ignace, "Canadian Aboriginal Languages and the Protection of Cultural Heritage" in Catherine Bell \& Val Napoleon, eds, First Nations Cultural Heritage and Law: Cases Studies, Voices, and Perspective (Vancouver: UBC Press, 2008).

29 Zoë Oxaal, "Removing That Which Was Indian from the Plaintiff: Tort Recovery for Loss of Culture and Language in Residential Schools Litigation” (2005) 68:2 Sask L Rev 367.

30 Christopher Powell, Barbaric Civilization: A Critical Sociology of Genocide (Montreal: McGill-Queen's University Press, 2011) at 5-6. Arguably, residential schools have to be considered in conjunction with displacement and the destruction of homelands to understand claims of genocide. Andrew Woolford, "Ontological Destruction: Genocide and Canadian Aboriginal Peoples" (2009) 4:1 Genocide Studies \& Prevention Intl J 81.

31 Convention on the Prevention and Punishment of the Crime of Genocide, 1948, 78 UNTS 277.

32 In a paper prepared for the TRC, Jayme Herschkopf and Julie Hunter conclude that while the separation of children from families and the consequent destruction of cultural ties could constitute an act covered by the convention, the requirement of intent to cause the group to perish as a physical or biological entity would not be fulfilled if the objective was purely to destroy the group's cultural identity. Jayme Herschkopf, Julie Hunter \& Laurel E Fletcher, “Genocide Reinterpreted: An Analysis of the Genocide Convention's Potential Application to Canada's Indian Residential School System” (Draft report prepared for the Truth and Reconciliation Commission of Canada, Winnipeg, April 2011) [unpublished]. 
$[I C C P R]^{33}$ and the 1966 International Covenant on Social, Economic and Cultural Rights [ICESCR $]^{34}$ provide for the protection of, and access to, "culture," as do the human rights instruments in the interAmerican system. ${ }^{35}$

The United Nations Declaration on the Rights of Indigenous Peoples [UNDRIP] also recognizes the importance of language and control over education for Indigenous peoples, such as in Article 13, which provides that Indigenous peoples have "the right to revitalize, use, develop and transmit to future generations their histories, languages, oral traditions, philosophies, writing systems and literatures." The UNDRIP further appears to address the policy behind IRS in more precise terms. Article 8.1 states that "Indigenous peoples and individuals have the right not to be subjected to forced assimilation or destruction of their culture," and Article 8.2 requires states to provide redress for actions that have "the aim or effect of depriving them of their integrity as distinct peoples, or of their cultural values or ethnic identities" and or for "any forced assimilation."

While some scholars consider it problematic to speak of cultural rights or define a "right to a cultural identity" in international human rights law because the above provisions are too broad or vague in ambit, there is an emerging jurisprudence of cultural rights as manifest through other enumerated rights such as to traditional lands or freedom of expression. ${ }^{36}$ There are other reasons to hesitate in framing the damage wrought by the IRS merely in terms of a right to culture, however. As General Comment no. 21 made by the UN Committee on Economic, Social and Cultural Rights in 2009 stresses, the ability of communities to pass on their values, religion, customs, language, and other cultural references, supported by the right to cultural life and the right to education, is also interdependent on the right to self-determination in Article $1 .{ }^{37}$ This provision, which is shared by both the ICCPR and the ICESCR, maintains the right of all peoples to self-determination, by virtue of which they "freely determine their political status and freely pursue their economic, social and cultural development." In other words, they should have the autonomy to selfregulate and create or follow their own laws in some areas.

Although historically associated with statehood, the above principle of self-determination has more recently been affirmed as being applicable to Indigenous peoples by Article 3 of the UNDRIP. ${ }^{38}$ According

33 International Covenant on Civil and Political Rights, 1966, 999 UNTS 171. Article 27 provides that ethnic and other minorities shall not be prevented from enjoying their own culture or using their own language.

34 International Covenant on Economic, Social and Cultural Rights, 1966, 993 UNTS 3. Article 15(a) recognizes “the right of everyone to take part in [an unspecified] cultural life."

35 American Declaration on the Rights and Duties of Man, 1948, 43 AJIL Supp 133 (1949); American Convention on Human Rights, 1969, 1144 UNTS 123.

36 Eg, Lopez Alvarez v Honduras, (2006) Inter-Am Ct HR (Ser C) No 124 at para 207, held that the mother tongue represents one of the most important elements of identity as a member of an Indigenous group because it is the vehicle for the expression and transmission of culture. See generally Marco Odello, "Indigenous Peoples' Rights and Cultural Identity in the Inter-American Context" (2012) 16:1 Intl J Human Rights 27; Megan Davis, "Indigenous Struggles in Standard-Setting: The United Nations Declaration on the Rights of Indigenous Peoples" (2008) 9:2 Melbourne J Intl L 26; Rodolfo Stavenhagen, "Cultural Rights and Human Rights: A Social Science Perspective" in Pedro Pitarch, Shannon Speed \& Xochitl Leyva Solano, eds, Human Rights in the Maya Region: Global Politics, Cultural Contentions and Moral Engagement (Durham, NC: Duke University Press, 2008).

37 UN Committee on Economic, Social and Cultural Rights, General Comment No. 21: Right of Everyone to Take Part in Cultural Life, UN Doc E/C.12/GC/21 (21 December 2009) at 1.

38 Currently endorsed by 148 nations, with the remainder either abstaining or absent from the vote. 
to most accounts, Article 3 and the right to self-determination are the cornerstone of the UNDRIP, and the provisions following it, including those concerning the protection of cultural identity, are best understood as translating that right into domestic systems. ${ }^{39}$ While an analysis of potential breaches of rights to cultural identity are beyond this article, it is sufficient for our purposes to note that in international law the assimilative practices of residential schools may best be understood as an attack on self-determination rather than on culture alone.

\section{Culture and Self-Determination in a Colonial Dialectic}

Domestically, the jurisprudence on Aboriginal rights seems to take "cultural loss" as the principal historical injustice inflicted on Indigenous peoples (although there is also now a shift towards thinking of the goal of section 35 of the Constitution Act as the reconciliation of sovereignties). ${ }^{40}$ Legal philosopher Gordon Christie suggests that the courts have been pursuing the protection of "Aboriginality" as the core of the rights "recognized and affirmed" by section 35 of the Constitution and tend to see self-determination and the revitalization of Indigenous legal traditions through that lens. In contrast, Indigenous peoples tend to see cultural revitalization as part of the project of self-determination. Nevertheless, he continues, since "self-determination" is simply a label for the "immense efforts that must be made to work against the effects of colonialism, [in order] to regain collective control over matters that are essential to the continuation of ways of life tied to a peoples' ancestors," the culture argument and the self-determination argument are inextricably linked. ${ }^{41}$

Consequently, not only is it important to consider rights to culture and self-determination together, but, as Christie argues, both cultural identity and self-determination must be seen against the backdrop of "the overarching effects of colonialism." 42 That is, while a distinctive identity or culture may be seen as justifying a claim of self-determination, and identities may in turn be valued because they are seen as the result of the efforts of Indigenous polities to express their collective selves, neither are natural starting points, and both have been shaped in response to outside - often hostile - forces. Understanding the harm of residential schools in this holistic, historical, and dialectical sense helps us widen the lens so as to point the finger of responsibility, not simply at an anachronous government policy but also at the very concept of modern, state-based sovereignty that would permit - as constitutionally valid - a like degree of control over Indigenous peoples. ${ }^{43}$ For although government power is currently constrained to varying degrees by the protections for Aboriginal rights in section 35, by the Canadian Charter of Rights and Freedoms, and by international human rights instruments, the basic jurisdiction over "Indians, and lands reserved for the

39 International Law Association, Committee on the Rights of Indigenous Peoples, “Interim Report, " The Hague Conference Report (2010) at 9, online: International Law Association <https:/www.ila-hq.org/en/committees/ index.cfm/cid/1024>; Davis, supra note 36 at 461.

40 See Felix Hoehn, Reconciling Sovereignties: Aboriginal Nations and Canada (Saskatoon: Native Law Centre, University of Saskatchewan, 2012). Constitution Act, 1982 (UK), 1982, c 11.

41 Gordon Christie, "Culture, Self-Determination and Colonialism: Issues around the Revitalization of Indigenous Legal Traditions" (2007) 6:1 Indigenous LJ at 20 [Christie, "Culture”].

$42 \quad$ Ibid at 21.

43 Although, even then, it is arguable that assimilation polices have not been abolished but, rather, changed form, such as through child welfare practices and resource development. 
Indians" in section 91(24) remains as it was in $1867 .{ }^{44}$ And while Canada's claim to sovereignty is frequently challenged in the critical literature, ${ }^{45}$ the concept of sovereignty that permitted colonialism is under-examined. ${ }^{46}$ Further, Christie's argument about the imbrication of culture and self-determination shifts the focus from harm to the capacity of people to respond to and exercise judgment in the face of violence and victimization and to create and maintain a legal order that deals with such things. ${ }^{47}$

The TRC made Indigenous traditions of peacemaking a feature of its practice, and it emphasizes in its report the need for reconciliation to include respect for Indigenous legal traditions. This section shows how that is intimately connected with understanding the harm of residential schools and other colonial policies, not just as damage to language, culture, and community but also as a fundamental assault on Indigenous sovereignty. While international law allows us to make one set of connections between culture and self-determination in the language of rights, I follow Christie in arguing that this or any other legal category is the product of collective work against colonialism. Legal traditions are thus central to the reinvigoration of Indigenous cultural identity with and through the exercise of self-determination because they are the vehicles - in this current context of the valorization of law and legal forms ${ }^{48}$ - for community control over structures and processes that produce and reproduce culture. ${ }^{49}$ Consequently, it is also then necessary to reframe constitutional rights in a way that redresses the damage to both Indigenous cultures and legal traditions. Finally, understanding any framing of the issues, whether as culture or selfdetermination, as produced by the histories of colonization turns our attention to deeper parts of legal thinking that have supported colonization, such as a particular way of thinking about sovereignty.

\section{B. Indigenous Law in the Canadian Legal System}

Historically and in contemporary times, Indigenous legal orders have been recognized by the nonIndigenous system to a limited extent. However, the project of "recognizing" or "making space" for Indigenous legal traditions within the Canadian system can be problematic for decolonizing strategies of mutual respect to the extent that the dominant system decides on the terms of recognition and that Indigenous agency is consequently eroded. ${ }^{50}$

44 Canadian Charter of Rights and Freedoms, Part 1 of the Constitution Act, 1982, being Schedule B to the Canada Act 1982 (UK), 1982, c 11.

45 See, eg, John Borrows, "Sovereignty's Alchemy: An Analysis of Delgamuukw v British Columbia" (1999) 37:3 Osgoode Hall LJ 537 [Borrows, "Sovereignty's Alchemy"].

46 Most work on this point concerns the inroads made by international law and globalization into traditional sovereignty. See, eg, Jean Cohen, "Whose Sovereignty? Empire versus International Law" (2004) 18:3 Ethics \& Intl Affairs 1.

47 Hadley Friedland, "Navigating through Narratives of Despair: Making Space for the Cree Reasonable Person in the Justice System" (2016) 67 UNBLJ 269 at 287.

48 John Comaroff \& Jean Comaroff, "Reflections on the Anthropology of Law, Governance and Sovereignty" in Franz von Benda-Beckmann, Keebet von Benda-Beckmann and Julia Eckert, eds, Rules of Law and Laws of Ruling: On the Governance of Law (London: Routledge, 2016) at 32-38.

49 See Christie, "Culture," supra note 41 at 25.

50 Glen Coulthard, "Subjects of Empire: Indigenous Peoples and the 'Politics of Recognition' in Canada" (2007) 6:4 Contemporary Political Theory 437. 


\section{Treaties, Indian Title, and Aboriginal Rights}

Early examples of colonial interactions demonstrate that colonists treated Indigenous peoples, at least to their faces and when it suited European interests to do so, as equal partners, following their protocols in practice where necessary ${ }^{51}$ and, in some cases, integrating themselves into Indigenous networks and family relations. ${ }^{52}$ Ironically, the Royal Proclamation of 1763 that formalized the practice of nation-tonation treaty making also spelled the beginning of the end of the treatment of Indigenous nations as having sovereign status (marking as it did the conclusion of hostilities between Britain and France), followed by the nineteenth-century policies of assimilation that we have examined. Nonetheless, these origins have provided a foundation of sorts for contemporary accounts of the place of Indigenous law in the constitutional make-up of Canada.

Treaty-making grounded the doctrine of Indian title, as first recognized in the US Supreme Court Marshall decisions, ${ }^{53}$ in that the practice was held to show that first discovery of a territory by a European power gave it the exclusive right to extinguish the right of occupancy of its original inhabitants. The place of Indigenous law, together with the status of First Nation peoples, was ambiguous in these decisions and would continue to be so in the Canadian jurisprudence that followed them. In the original Marshall doctrine, "Indians" were sovereign peoples and owners of the soil prior to the arrival of Europeans, but they were liable to lose their title through conquest or cession to the English government by reason of the latter's "discovery" of the territory, a principle that can only be traced to an assumption of European/Christian superiority. It was, as one US legal scholar puts it, a transient Indian sovereignty used as a device that would immediately efface itself. ${ }^{54}$

The basics of this doctrine survive in Canadian Aboriginal title as elaborated by the Supreme Court of Canada: Indian title means that "when the settlers came, the Indians were there, organized in societies and occupying the land as their forefathers had done." 55 In other words, these societies were organized by laws that survived British claims of sovereignty, presumably according to the doctrine of continuity in which the pre-existing laws of colonized peoples persisted until abrogated or altered by colonial authorities, ${ }^{56}$ such that their prior occupation crystalized into a form of title that burdened the Crown's underlying title to land. In Delgamuukw v British Columbia, the relationship between the common law and pre-existing systems of Aboriginal law is said to be one of the sources of Aboriginal title. ${ }^{57}$ The earlier rule from $R$. $v$ Van der Peet, which holds that evidence of Aboriginal rights must be considered both from the perspective of the common law and from the Aboriginal perspective, ${ }^{58}$ is extended in Delgamuukw to the character of

51 Arthur Ray \& Donald Freedman, 'Give Us Good Measure': An Economic Analysis of Relations between the Indians and the Hudson Bay Company before 1763 (Toronto: University of Toronto Press, 1978) at 231-260; John Borrows, "Wampum at Niagara: The Royal Proclamation, Canadian Legal History, and Self-Government" in Michael Asch, ed, Aboriginal and Treaty Rights in Canada (Vancouver: UBC Press, 1997) 169.

52 Sylvia Van Kirk, Many Tender Ties: Women in Fur-Trade Society in Western Canada 1670-1870 (Norman: University of Oklahoma Press, 1983).

53 Beginning with Worcester v Georgia, (1832) 31 US (6 Pet) 515.

54 Peter D’Errico, “John Marshall: Indian Lover?” (2000) 39:3 Journal of the West 19.

55 Calder v British Columbia (AG), [1973] SCR 313 at para 328, 4 WWR 1 (Judson J).

56 Mark D Walters, "The 'Golden Thread' of Continuity: Aboriginal Customs at Common Law and under the Constitution Act 1982" (1999) 44:3 McGill LJ 711.

57 Delgamuukw, supra note 7 at para 114 (Lamer CJ).

58 Van der Peet, supra note 8 at para 49 (Lamer CJ). 
Aboriginal title itself. It is sui generis in the sense that "its characteristics cannot be completely explained by reference either to the common law rules of real property or to the rules of property found in Aboriginal legal systems." 59

But, in order to justify Parliament's power to extinguish or infringe Aboriginal rights as well as its own rights to the land, the court argued that "there was from the outset never any doubt that sovereignty and legislative power, and indeed the underlying title, to such lands vested in the Crown." ${ }^{.60}$ This unquestioned basis of Crown sovereignty can only be, in the absence of a war of conquest or a formal session of Indigenous sovereignty, that Canada was terra nullius because its peoples were not civilized societies governed by law. ${ }^{61}$ The "reconciliation" of these contradictory premises - of the prior occupation of North America by Aboriginal peoples with the assertion of Crown sovereignty - is taken to be the objective of the recognition of rights in section 35. Taking account of both the perspective of the common law and Aboriginal perspectives, placing equal weight on each, is said to be the means to achieve it. ${ }^{62}$ However, the test for Aboriginal rights in Van der Peet embodies only the thinnest recognition for Aboriginal legal orders, treating them simply as sources of evidence for the brute facts of Indigenous existence prior to contact.

Stronger acknowledgement of legal orders in the form of self-government can be found in later cases. In $R$. v Pamajewon - a case defending a right to operate high-stakes gambling on reserve as an exercise of self-government - the Court "assumed without deciding" that section 35 included self-government rights, but held that they would have to be established on the same test as other rights, namely, as a specific practice originating in pre-contact times.$^{63}$ The space for Indigenous self-government within the Canadian constitutional order was squarely at issue in Campbell v British Columbia, following the signing of the Nisga'a Treaty in 1998, in which the Nisga'a Lissims government was provided with legislative jurisdiction, exclusive of federal or provincial jurisdiction in some matters. Justice Williamson for the Supreme Court of British Columbia held, significantly, that the power to make and rely on Aboriginal law survived Confederation and has not been extinguished by the distribution of legislative powers in the Constitution. ${ }^{64}$ Finally, the Supreme Court of Canada in Haida Nation v British Columbia (Minister of Forests) described treaties as reconciling "pre-existing Aboriginal sovereignty with assumed Crown sovereignty," thus annulling the assumption of terra nullius and shifting the attainment of de jure (legal) rather than de facto Canadian Crown sovereignty to some point in the future through honourable negotiation. ${ }^{65}$ These decisions, while never grappling substantively with Indigenous law, do establish a framework or a space for doing so within the existing state system.

59 Delgamuukw, supra note 7 at para 112 (Lamer CJ).

${ }^{60} R$ v Sparrow, [1990] 1 SCR 1075 at para 283 [Sparrow].

61 Michael Asch, "From Terra Nullius to Affirmation: Reconciling Aboriginal Rights with the Canadian Constitution" (2002) 17:2 Can J Law \& Soc'y 23 at 23-39

62 Delgamuukw, supra note 7 at para 148 (Lamer CJ).

${ }^{63} R v$ Pamajewon, [1996] 2 SCR 821 at para 24, 138 DLR (4th) 204 (Lamer CJ).

64 Campbell v British Columbia (AG), 2000 BCSC 1123 at para 86.

65 Haida Nation v British Columbia (Minister of Forests), [2004] 3 SCR 511 at para 20 (McLachlin CJ). 


\section{Criminal and Family Law}

Historically, there was some recognition of Indigenous law in criminal and family matters. For instance, a hybrid approach to the treatment of offenders in seventeenth-century New France emerged as the "synthesis of individual responsibility practised by the French, and the acts of compensation and reconciliation common among Aboriginal peoples." "6r From the nineteenth century on, decisions were made by courts throughout Canada recognizing customary marriages as valid legal marriages if they had certain features. ${ }^{67}$ Customary adoption has also been recognized by both statute and common law across Canada since 1961, mostly for the purposes of accessing benefits and executing formalities on behalf of the child. ${ }^{68}$ While, prior to 1982, courts followed common law requirements for recognizing the validity of local custom, ${ }^{69}$ since the constitutionalization of Aboriginal rights, the question is whether the practices form an integral part of the distinctive culture" of the group in question, ${ }^{70}$ giving rise to a right that has not been extinguished. ${ }^{71}$

The family status examples illustrate in a nutshell the problems with state recognition of Indigenous laws as practices. First, is the effect of recognizing customary arrangements to be that of statutory forms or that of Indigenous custom? In the case of adoption, most litigation arises because the plaintiffs seek the benefits or rights that accrue to official adoptive parents and, thus, seek to have their customary arrangement treated as equivalent to other adoptions. There are some major differences in the content of adoption practices, however. For example, statutory adoptions usually maintain closed records and terminate all rights and duties of the birth parents, while customary adoptions are often characterized by openness and a continued relationship between birth parents and the adopted child. ${ }^{72}$ On the other hand, state courts cannot pretend to be able to give purely customary effect to custom, so there is always some form of translation. But how should it be done? A parallel question arises in Aboriginal rights jurisprudence and is answered in $R v$ Marshall; $R v$ Bernard: the Aboriginal practice is to be translated, as faithfully and objectively as it can be, into a modern legal right. ${ }^{73}$ Aboriginal rights will be such things as the right to exclusively possess land and the right to fish, hunt, and cut timber, for example. Although they have a unique treatment in law because of their constitutional status (they can only be infringed if the fiduciary duties of the Crown are upheld), they are nonetheless rights cognizable within the common law that may be enforced by the usual panoply of remedies available to the court.

66 Jeremy Webber, "Relations of Force and Relations of Justice: The Emergence of Normative Community between Colonists and Aboriginal Peoples" (1995) 33:4 Osgoode Hall LJ 623.

67 See Norman Zlotkin, "From Time Immemorial: The Recognition of Customary Law in Canada" in Catherine Bell \& Robert Peterson, eds, Protection of First Nations Cultural Heritage: Laws, Policy and Reform (Vancouver: UBC Press, 2009) at 346-348. Manychief v Poffenroth, (1994) 25 Alta LR (3d) 393, which more recently held that the earlier criteria for recognition is the "validity in the community, voluntariness, exclusivity, and permanence."

68 Cindy L Baldassi, "The Legal Status of Aboriginal Customary Adoption across Canada: Comparisons, Contrasts, and Convergences" (2006) 39:1 UBC L Rev 63. Note also Quebec Bill 81 on adoption, which provides that "the conditions of any Aboriginal custom in Quebec which is in harmony with the principles of the interest of the child, of the respect of his or her rights and of the consent of the parties involved, may replace the conditions for adoption set out in the law."

69 Zlotkin, supra note 67 at 350.

70 Van der Peet, supra note 8 at para 11 (Lamer CJ).

71 Sparrow, supra note 60 at paras 62-83.

${ }_{72} S K K$ v JS, [1999] NWTJ 94 (SC).

73 Marshall; Bernard, supra note 10 at para 48 (McLachlin CJ). 


\section{The Problem of Translation}

This brings us to a second closely related problem. If Indigenous customary institutions are to be treated as creating the same rights and obligations as common law ones, then there has to be some way of distinguishing what will be recognized - some set of essential criteria applied by the judiciary - that sets apart what will be seen, for instance, as "marriage" from what cannot be recognized in this way. On the Aboriginal title question in Marshall; Bernard, one issue was that, while the test for title required claimants to prove their ancestors had possessed traditional Mi'kmaq territories exclusively, the key witness on Mi'kmaq law consistently made the point that Mi'kmaq culture operated on the principle of inclusion rather than exclusion. Because the effects of, or remedies for, Aboriginal title are based on exclusive possession as the core of the idea of title, customary forms of title based on an alternative philosophy were held to fall outside the recognizable forms of tenure. ${ }^{74}$

The use by the state of essential criteria and a European epistemological framework to recognize Indigenous legal orders has been criticized as ethnocentric and colonial by many authors. ${ }^{75}$ Yet despite the adoption of the sui generis framework for Aboriginal rights and talk of reconciling two perspectives, argues Sákéj Henderson, "the judiciary struggles to generate a trans-systemic method to displace the Eurocentric monopoly and baggage of colonial attitudes and sympathies embedded in familiar judicial methods, evidence, and reasoning." ${ }^{, 76}$ According to him, some of the profound challenges posed by developing a constitutionalism that is "trans-systemic" or "intersocietal" are as fundamental as the differences between Indigenous verb-centred languages, a holistic approach to life in which all things are related and a performance-based tradition, on the one hand, and the courts' epistemology derived from Enlightenment philosophy that prizes the concrete categories of noun-based languages, objective reason, and individual freedom, on the other hand. Only an approach that takes into account both perspectives on rights and is willing to shake European concepts to their foundations (as well as Indigenous ones, but this has long been the case) will be a genuine reconciliation. In an inter-cultural environment, translation is inevitable, but I will suggest that there are other approaches to translation than the one offered by McLachlin CJ.

In literary translation theory, there are two basic approaches. One is dubbed the invisible translator when reading the translated text, one could not guess that it was not originally produced by a Native speaker. The second tries to respect the original language by letting its "foreign-ness" show through. ${ }^{77}$ Thus, while a translation can never fully reproduce the effects, symbolism, resonance, poetry, and nuance of the original, it can do something to let the distinctiveness of the original language appear via the

74 Ibid at para 81. This core requirement has remained in the restatement of the requirements of Aboriginal title in the successful Tsilhqot'in Nation claim. Tslhqot'in v British Columbia, 2014 SCC 44 at paras 47-49, [2014] 2 SCR 257 [Tsilhqot'in].

75 See, eg, Borrows, “Sovereignty's Alchemy," supra note 45 at 557; Gordon Christie, “A Colonial Reading of Recent Jurisprudence: Sparrow, Delgamuukw and Haida Nation" (2004) 23:1 Windsor YB Access Just 17; James (Sákéj) Youngblood Henderson, "Constitutional Vision and Judicial Commitment: Aboriginal and Treaty Rights in Canada" (2010) 14:2 Austl Indigenous L Rev 24; Celeste Hutchinson, "Reparations for Historical Injustice: Can Cultural Appropriation as a Result of Residential Schools Provide Justification for Aboriginal Cultural Rights?" (2007) 70:2 Sask L Rev 453.

76 Ibid at 31.

77 Lawrence Venuti, The Translator's Invisibility: A History of Translation (Milton Park, UK: Routledge, 1995). 
disruption of the usual way of speaking or writing - using nouns as verbs or making compound nouns out of separate words in English, for instance. In trying to "do justice" to the original in this ethical way, the language of translation also becomes altered; we both see a particularity in the language that was perhaps previously taken for granted, and we alter it by making new forms of expression possible. ${ }^{78}$ In the recognition of Indigenous legal orders in Canada, this can only happen by trying to grapple with Indigenous languages and the lifeworlds they reflect and constitute.

Aboriginal rights might be seen as addressing the loss of culture suffered through colonization by offering constitutional protection for practices that are "integral to the distinctive culture" of Aboriginal peoples. ${ }^{79}$ If so, understanding that the harm is both to the cultural distinctiveness and the right to selfdetermination, as discussed above, instructs us to lean heavily on the parts of Aboriginal rights decisions that locate the source of rights in Indigenous law and that characterize them as an inter-societal legal hybrid rather than a set of anomic practices that have to find equivalents in the common law. As Indigenous scholars such as John Borrows and Sákéj Henderson have been stressing, the challenge is to educate non-Aboriginal judges, lawyers, and law students to comprehend Indigenous legal traditions. ${ }^{80}$ But, as Val Napoleon comments on the reconciliation process more broadly, the objective of education and information sharing as a path to reconciliation cannot be a one-way street - an invitation to look at "Aboriginal people under glass." ${ }^{\not 1}$ Non-Indigenous people must also be called on to explain their own culture and legal traditions. The third part of this article now presents a sketch of such an approach.

\section{INDIGENOUS UNDERSTANDINGS OF LAW, SOVEREIGNTY, AND RECONCILIATION}

This section proposes to investigate a small sample of the resources offered by the great variety of Indigenous traditions in Canada in thinking about "reconciliation" and, through a larger lens, "law" and "sovereignty." This exercise, first, is a gesture to redress the harm constituted by lack of respect for, and the progressive destruction of, Indigenous languages and ways of life. Second, it is necessary in order to avoid the problematic presumption that the reconciliation of peoples can happen without understanding, from multiple perspectives, what reconciliation is, whom it involves, and how it can happen. The process of selecting examples of "reconciliation" requires some reflection, as it begs the question of the core point of departure - are we to compare healing practices, approaches to peacemaking and the resolution of interpersonal disputes, redressing harm, or wrongdoing, or protocols that inform relations with other polities? I have tried not to assume that there is an essential content to reconciliation. Rather, the examples that have been chosen - Algonquian circle philosophies, the Haudenosaunee condolence ceremony, and the Gitxsan feast - are those about which a great deal has been written and that are often cited in restorative justice or alternative dispute resolution literature. I then use key terms and practices as a gateway into a set of ways of thinking, being, and doing in order that the comparison is of a much larger sensibility around reconciliation.

\footnotetext{
78 George Steiner, After Babel: Aspects of Language and Translation, 2d ed (Oxford: Oxford University Press, 1992) at 67, n 315 .

79 Van der Peet, supra note 8 at 46 (Lamer CJ).

80 Borrows, "Indigenous Constitution," supra note 16; Henderson, supra note 75 at 36.

81 Napoleon, "Reconciliation," supra note 5 at 183.
} 
In researching these examples, I have relied on published materials, supplemented by conversations with practitioners and language speakers. Indigenous philosophies and practices often cannot be described in English without distortion, although there may be an existing English vocabulary that is used by people. On the other hand, to speak of "distortion" suggests that there is a definitive original, while, clearly, there are many different versions of traditional stories and ceremonies and multiple perspectives as to what they mean. My approach has been that of ethical translation mentioned in the second part of this article. I have attempted to be sensitive to the contexts in which words are used and to let the "trace of the foreign" show through in the English account, so that the naturalness of the legal and philosophical traditions associated with English is put into question.

\section{A. Algonquian: The Circle}

The symbolism of the circle has been widely adopted in alternative justice models as connoting inclusiveness, interconnection, and renewal. In the logo of the TRC, the "circle of life" is said to be where people join together to share the truth. ${ }^{82}$ In the sentencing circles that have been adopted in the Canadian criminal justice system as an alternative to conventional punitive hearings for Indigenous offenders, the geometry of the circle is symbolic of the organization of the sentencing process. Just as there is no top or bottom, and each point is equidistant from the centre, a sentencing circle ideally involves judge, offender, victim, families, and community members in a non-hierarchical fashion as equal participants. ${ }^{83}$ A circle's perimeter faces all directions at once, standing for a holistic approach to justice that considers the larger context of wrongdoing and the network of people that it touches. Further, because tracing the circumference of a circle brings you back where you started, the circle represents cycles and renewal and, thus, the possibility of healing wounded relationships that reconciliation promises.

Indigenous circle philosophies are said to be modeled on what is found in Creation. As Oglala Sioux Black Elk states, the "Power of the World always works in circles" - in the orbs of the sun and moon, the whirling wind, the nests of birds, the seasons, and the lives of humans. ${ }^{84}$ As an embodiment of renewal, balance, equality, and harmony, the circle is a sacred symbol in many Indigenous traditions. In some traditions, the circle is part of an elaborate set of teachings, such as those associated with the medicine wheel. This part of the article will draw on Algonquian language understandings of the circle as an image of reconciliation, focusing on two aspects - renewal and holism - that seem to produce promising mistranslations. ${ }^{85}$

82 Truth and Reconciliation Commission, online: $<$ http://www.trc.ca/websites/trc-institution/index.php? $\mathrm{p}=14>$.

83 Jane Dickson-Gilmore \& Carol LaPrairie, Will the Circle Be Unbroken? Aboriginal Communities, Restorative Justice and the Challenges of Conflict and Change (Toronto: University of Toronto Press, 2005) at 133.

84 Quoted in Norbert Hill, Words of Power: Voices from Indian America (Golden, BC: Fulcrum Publishing, 1994) at xi.

85 This language group includes many First Nations languages, including Cree, Ojibwa, and Mi'kmaq. 


\section{Giiwitaa (around); giiwitaashkaa (s/he goes around in a circle) (Ojibwa) ${ }^{86}$}

Because Algonquian languages are not primarily noun based, "circle" translates only as a verb (doing something in a circle) or as a preposition that involves a relation (going around something). The action of moving in a circular fashion, tracing a path that ends where it began, is what speaks to cycles and the "renewal" aspect of reconciliation processes. However, someone who has learned "circle" as an element of Euclidean geometry may understand this differently than someone who has learned "giiwitaa." In an informative comparative analysis of the circle on which this section draws heavily, Ian Turner argues that since the path of a geometric circle is limited to a predetermined course, it has become associated in Western traditions with the predictability of nature, with primitivism and mindless repetition, in contrast to the linear character of human progress that breaks free of the limitations of nature and reaches "ever closer to God or ... the eternal truths of science. ${ }^{" 88}$ The pejorative associations of the circle in European languages persist - circular arguments do not follow the logical steps of reasoned discourse; running circles around someone is to confuse and take advantage of them; we turn in circles when we are lost and directionless. ${ }^{89}$

Turner suggests that being informed by what he terms the "linear circle" has led Europeans and their descendants to misunderstand and denigrate circles in Indigenous thought. ${ }^{90}$ The assumption is that returning to the same point is pure repetition and, hence, devoid of originality or progress. However, to learn the circle as an action in time, (verb) based on personal experiences with movement or cycles in nature rather than as an abstract entity (noun), is to understand that recurring events are both the same and different than preceding ones. Turner borrows the aphorism "you can never step in the same river twice" to highlight the difference. The thing that persists of the river, unchanging over time - its name or its geographic location - is an abstraction, the idea of a river. Experientially, though, the river is an accumulation of things that we see, hear, feel, taste, and smell and that is constantly in flux. Spring may come around again, and the same trees will flower, but they are taller now and so on. Thus, circular thinking can both adhere to something done in the past and originate something new in the same moment.

The contrast in these understandings of circle can be reflected in attitudes relating to reconciliation. For the linear circle, the work of remembering might be derided as going over old ground. Reconciliation might be seen as requiring people to "forgive and forget" or to "move on"; the TRC mandate, for instance, mentions a desire to "put the events of the past behind us." "There may be an instinct to measure progress and positive change in linear steps so that frustration arises if the discussion of the issues sees the same comments, memories, and claims recurring. For the second understanding of circle, remembering could

\footnotetext{
86 John Borrows, personal communication (June 2012). The Ojibway People's Dictionary gives giiwitaa-aya 'ii as “all around it." Ojibway People's Dictionary, online: <http://ojibwe.lib.umn.edu>.

87 Leroy Little Bear, "Jagged Worldviews Colliding" in Marie Battiste, ed, Reclaiming Indigenous Voice and Vision (Vancouver: UBC Press, 2000) at 78.

88 Ian Turner, Changing the Subject: Objectivity, the Trickster and the Transformation of the Western Academy (MA thesis, University of Toronto, 2000) at 12.

89 See also Roland Chrisjohn \& Sherri Lynn Young, with Michael Maraun, The Circle Game: Shadows and Substance in the Indian Residential School Experience in Canada, revised ed (Penticton, BC: Theytus Books, 2006) ch 8.

90 Turner, supra note 88 at 14-16.

91 Indian Residential Schools Agreement, supra note 3.
} 
be re-membering, where returning to the "same place" means reconstituting its parts. ${ }^{92}$ This understanding sees the dialectic between repetition and originality as iteration - while themes, actions, or memories may be revisited, the context is never the same and so the meaning evolves. ${ }^{93}$ Thus, giiwitaashkaa gives us one way to think about the relationship - complicated in transitional or restorative justice - between memory and the past, on the one hand, and change or renewal and the future, on the other. In law, more generally, there is an assumed linear temporality in modern legality that moves from sovereign will to enactment in written rules and enforcement. A legal rule is made, then it exists like the geographical river in abstraction until it is altered. Algonquian verb-based law - a direction taken by John Borrows, Sakej Henderson, and Leroy Little Bear but which cannot be explored further here - suggests a different configuration of meaning and time, of will and action. ${ }^{94}$

\section{Msit No'kmaq (all my relations) (Mi'kmaq)}

In English, reconciliation is an inherently relational concept; you have to reconcile yourself with someone or to something. In its Christian origins, and in the secular morality that grew out of them, reconciliation is the restoration of a wrongdoer to God/the community after the violation of God's law/binding community norms has alienated him or her. ${ }^{95}$ In contemporary restorative justice literature, reconciliation offers itself more broadly as a solution once injustices are understood in terms of abuse of power or trust, domination, lack of respect - in brief, because of a conflicted relationship - rather than simply just in terms of loss or damage, for which restoration or redistribution might be more apt responses. "Restorative justice" addresses a variety of relationships: the direct relationship between victim and offender, their families and immediate community, and the broader social structures that foster the abuse of power over others. ${ }^{96}$ While giiwitaashkaa helps us focus on renewal, msit no 'kmaq encompasses the fundamental holistic approach of Algonquian circle philosophies that can speak to the relational aspects of reconciliation. ${ }^{97}$ Similar phrases, translated as "all my relations" from Ojibwa, Cree, and other North American Indigenous languages, frequently conclude prayers as a way of reminding people of their

92 Turner, supra note 88 at $18-19$.

93 For contemporary European philosophy that resonates with this, see Jacques Derrida, Signature, Event, Context, translated by Samuel Weber \& Jeffrey Mehlman, in Gerald Graff, ed, Limited Inc (Evanston, IL: Northwestern University Press, 1988); see also Jacques Derrida, "Différance" in Jacques Derrida, Margins of Philosophy, translated by Alan Bass (Chicago: Chicago University Press, 1982).

94 Borrows, Indigenous Constitution, supra note 16 at 245; James (Sakej) Youngblood Henderson, "First Nations Legal Inheritances in Canada: The Mi'kmaq Model” (1996) 23 Manitoba LJ 1; Little Bear, supra note 87.

95 Andrew Schaap, Political Reconciliation (New York: Routledge, 2005) at 9, 77-78; Victor van Bijlert, "The Meaning of Reconciliation" in Jerald Gort, Henry Jansen \& Hendrik Vroom, eds, Religion, Conflict and Reconciliation (Amsterdam: Rodopi, 2002) at 372-373.

96 See Dennis Sullivan \& Larry Tifft, Restorative Justice: Healing the Foundations of Our Everyday Lives (Monsey, NY: Criminal Justice Press/Willow Tree Press, 2001); Pranis Kay, "Restorative Justice, Social Justice, and the Empowerment of Marginalised Populations" in Gordon Bazemore \& Mara Schiff, eds, Restorative Community Justice: Repairing Harm and Restoring Community (Cincinnatti, OH: Anderson Publishing, 2001) at 287-306.

97 Gerald Gloade, Coming Full Circle: Redefining “Effectiveness” for Aboriginal Justice (MA thesis, Dalhousie University Department of Sociology and Social Anthropology, 2011) at 23. 
interconnection and responsibilities to others, of affirming a "foundational understanding that all things exist contingently, in respect of one another." 98

Which are the relations encompassed by the circle of the TRC? In 1996, when the RCAP suggested reconciliation as a way forward, it envisaged political reconciliation between the Canadian and Indigenous governments or between the peoples that they represented. In the Supreme Court of Canada's interpretation of constitutional Aboriginal rights, it is the reconciliation of societies, laws, and perspectives that is the objective of section 35. The TRC's mandate calls reconciliation "an ongoing individual and collective process" and suggests that the parties to it range from former students and their families to the government and the Canadian people. Statements from both officials and lay participants in TRC processes, however, suggest that interpersonal reconciliation - the importance of forgiveness and personal healing - is primary. ${ }^{99}$ And while some former students have thought of the IRS teachers and administrators as the audience for their testimony, sometimes expressing a wish to be able to confront and/or forgive their teachers in person, ${ }^{100}$ one observer of the Winnipeg gathering in June 2012 wrote:

Reconciliation, conceptualised as a relationship between Indigenous peoples and the nation, came second to repairing the intimate relationships between family members. In many cases, non-Indigenous Canadians were not the intended audience for these testimonies. Indigenous family members and communities were often the direct audience, with non-Indigenous Canadians playing an indirect or secondary role as listeners. ${ }^{101}$

The sense of who is immediately included in the circle of reconciliation is thus something being rewritten by participants. But the dominance of an interpersonal model makes it hard to conceive of broader political reconciliation (between peoples or between governments). As Commissioner Murray Sinclair said, "I have never met anyone that wants to be reconciled with the government. One forgives people, not institutions." 102 I will return to the connections between the personal and the political in the following section of this article.

Conceptually, the idea of relationship that is borrowed from the Christian/secular moral version of reconciliation is problematic in the context of colonial injustice because it presupposes a single set of norms that bind a single community. ${ }^{103}$ The knowledge that we are all related does not mean that we are the same, but it does compel us to acknowledge the impact of our actions on others. However, notwithstanding the lack of a mandate to investigate specific events or allocate responsibility to wrongdoers, other aspects of responses to residential schools also serve to minimize the focus on those

\footnotetext{
98 Wapshkaa Ma'iinan (Aaron Mills), “Aki, Anishinaabek \& kaye tahsh Crown” (2010) 9:1 Indigenous LJ 107 at 110.

99 Matt James, "A Carnival of Truth? Knowledge, Ignorance and the Canadian Truth and Reconciliation Commission" (2012) 6:2 Intl J Transitional Justice 1 at 13-14.

100 Andrew Sniderman, "Residential Schools: Survivors Share Their Pain," Montreal Gazette (7 May 2011)

101 Naomi Angel, "Before Truth: The Labours of Testimony and the Canadian Truth and Reconciliation Commission" (2012) 53:2 Culture Theory and Critique 199 at 208-209.

${ }_{102}$ See quote in James, supra note 99 at 194.

103 Schaap, supra note 95 at 78.
} 
who have "behaved as if they had no relatives." ${ }^{104}$ For example, Cree Elder Stan McKay is critical of the response to residential schools that established only an Aboriginal Healing Foundation. ${ }^{105}$ Roland Chrisjohn and colleague's satirical list of criteria for residential school syndrome that diagnoses colonial society as the one suffering from an illness makes the same point. ${ }^{106}$ Putting only Indigenous culture and histories under the microscope risks making non-Indigenous culture invisible or taken for granted. ${ }^{107}$

Msit no'kmaq gives us one further observation to make about the relationships involved in reconciliation. "All my relations" refers not only to human others but also to animals, plants, minerals, and spirits. ${ }^{108}$ Names for elements of the non-human world underline this idea - grandfather sun, grandmother moon, and mother earth - as do dodem or clan identities that are based on animals, grammatical categories that include as animate persons what Europeans think of as belonging to the natural world (flint stone, winds, the sun), ${ }^{109}$ and hunting as a "gift economy" in which animals exercise agency and follow social norms. ${ }^{110}$ "Aboriginal healing" is not sufficient for reconciliation, and Stan Mackay asks: "[I]s it possible to speak about reconciliation without the conversation including the discussion of the health of the whole creation?" "111 If the reconciliation process in Canada has to face up to the larger injustices of colonization, including dispossession and the destruction of ecosystems, in order to be genuine, then arguably the most unhealthy practice standing in the way of reconciliation is the relationship of possessive acquisition that the state and state laws have with the land and its resources. ${ }^{112}$

\section{B. Haudenosaunee: Condolence Ceremonies}

The Haudenosaunee condolence ceremonies are often cited as one of the Indigenous traditions of reconciliation in Canada and are notable because of the influence they had in the early era of diplomatic relations between Europeans and Indigenous peoples. ${ }^{113}$ They are particularly interesting because, in linking personal and societal healing, they traverse some of the same psychological and political terrains as reconciliation but provide an alternative way of linking the two. The English word condolence is the expression of sympathy with the grief of others, and some sources say that the original Haudenosaunee ceremony was invented along with the clan system, so that those clans mourning the loss of a relative

${ }^{104}$ Robert Yazzie, "Healing as Justice: The Navajo Respones to Crime" in Wanda D McCaslin, ed, Justice as Healing: Indigenous Ways (St Paul, MN: Living Justice Press, 2005) 121 at 123.

105 Stan McKay, "Expanding the Dialogue on Truth and Reconciliation - In a Good Way" in Marlene Brant Castellano, Linda Archibald and Mike DeGagné, eds, From Truth to Reconciliation: Transforming the Legacy of Residential Schools (Ottawa: Aboriginal Healing Foundation, 2008).

${ }^{106}$ Chrisjohn \& Young, supra note 89 at 87.

107 Napoleon, "Reconciliation?" supra note 5.

${ }^{108}$ Winona LaDuke, All Our Relations: Native Struggles for Land and Life (Cambridge, MA: South End Press, 1999); Gregory Cajete, Native Science: Natural Laws of Interdependence (Santa Fe, NM: Clear Light Publishers, 2000).

${ }^{109}$ Hallowell A Irving, "Ojibwa Ontology, Behaviour and World View” in Graham Harvey, ed, Readings in Indigenous Religions (London: Continuum, 2002) at 22-29.

110 Paul Nadasdy, "The Gift in the Animal: The Ontology of Hunting and Human-Animal Sociality" (2007) 34:1 American Ethnologist 25.

111 McKay, supra note 105.

112 Nicole Graham, Lawscape: Property, Environment Law (Abingdon, UK: Routledge-Cavendish, 2010).

${ }^{113}$ Mark D Walters, "The Jurisprudence of Reconciliation: Aboriginal Rights in Canada" in Will Kymlicka \& Bashir Bashir, eds, The Politics of Reconciliation in Multicultural Societies (Oxford: Oxford University Press, 2008) 165 at 170-171. 
would be condoled by those in the other moiety, enabling them to recover from their grief and perform once again the tasks that were crucial to the survival of their societies. ${ }^{114}$ Famously, the Haudenosaunee epic Kayaneren 'kó:wa tells that the condolence ceremony was revived, at a time of internecine warring and blood feuds, by the cultural hero Deganawida (the Peacemaker) and performed by him for Hiawatha when the latter was incapacitated by grief at the death of his daughters - tears clouded his eyes, grief clogged his throat, and pain rang through his ears. The core of the ceremony is called, in academic literature, the "requickening address," in which those who are not mourning, and have a clear mind, metaphorically wipe the eyes of the mourners with deer skin, clear their throats with cool water, and unplug their ears with a soft feather. ${ }^{115}$

The ceremony is used not only at funerals but also to install a new roianer (chief) when the previous roianer has passed away, as a greeting ceremony after a long journey, in making peace with enemies, and in diplomatic relations with allies. ${ }^{116}$ Recently, a condolence was held for the whole community of Kahnawake to help "clear their minds" of the fear, anger, and sadness accumulated over the 285 years of the settlement. ${ }^{117}$ Thus, the ceremony appears to be both polyvalent - appearing in different forms and social contexts - and ecumenical, used also in relations with non-Haudenosaunee and non-Indigenous allies. For example, in the adapted condolence ritual that has been identified in the eighteenth-century treaties between the Haudenosaunee and the English, preliminary ceremonies directed towards reestablishing good relations and opening the way for clear communication exhorted the visiting party to "put away grief" and be cheerful among friends, in an echo of the traditional Iroquoian "welcome at the wood's edge" ritual used between visiting allies. ${ }^{118}$

The hope of welcoming European peoples into the kinship of the metaphoric "longhouse" of the Haudenosaunee confederacy was abandoned after they showed themselves unwilling to accept life according to the Great Law. It was exchanged for a metaphor of linkage, whereby, in Haudenosaunee orations, a rope is tied from a European ship to a rock in Onandaga country, replaced by an iron chain and then a silver one. 119 Diplomatic meetings are construed as "polishing the covenant chain" and memorialized in the two-row wampum belt that contains its own imagery of a European ship and a Haudenosaunee canoe (two purple rows) travelling together, but separately, in a white river of peace. Although the Haudenosaunee developed a new foreign policy with respect to the newcomers in which each group would maintain its distinctiveness while living side by side, they continued to use condolence to frame their meetings.

\footnotetext{
114 Teyowisonte Thomas Deer, "Releasing the Burden: Haudenosaunee Concept of Condolence," Eastern Door (28 September 2001) at 14 .

115 The classic source is JNB Hewitt, "The Requickening Address of the Iroquois Condolence Council," edited by William Fenton (1944) 34:3 J Washington Academy of Sciences 65; see also Doug George-Kanentiio, “Atonement among the Haudenosaunee” (2009) 20:3 Indigenous Policy J, online: <https://ipjournal.wordpress.com>.

116 These forms are considered by Denis Foley, "Iroquois Mourning and Condolence Installation Rituals: A Pattern of Social Integration and Continuity" in Christine Sternberg Patrick, ed, Preserving Tradition and Understanding the Past: Papers from the Conference on Iroquois Research, 2001-2005 (Albany: New York State University, 2010) 24.

117 Teyowisonte, supra note 114.

118 Michael M. Pomedli, "Eighteenth-Century Treaties: Amended Iroquois Condolence Rituals" (1995) 19 American Indian Q 319 at 322; Francis Jennings, ed, The History and Culture of Iroquois Diplomacy: An Interdisciplinary Guide to the Treaties of the Six Nations and Their League (Syracuse: Syracuse University Press, 1985).

119 Matthew Dennis, cited in Regan, supra note 4 at 154
} 


\section{Condolence: The Political is Personal}

The common factor throughout these different contexts is related to the ordinary English meaning of condolence as an expression of sympathy, but there is a deeper meaning that has both a secular and a spiritual dimension. In a secular sense, the condolence is important in helping individuals overcome the psychological suffering that comes with grief and loss so that the normal cycle of life may be restored, and they may once more take up their life duties on which a functioning society depends. ${ }^{120}$ One contemporary (Mohawk/Kanienkeha) word for the ceremony is Ka'nikonhrakétsko, which means "lifting up the minds," ${ }^{121}$ where the root O'nikonrha supplies words relating to what goes on in your head but including thinking, feeling, and attitude. ${ }^{122}$ However, these psychological aspects of individual grief are also important in civil protocols, such as the chief installation ceremony and the welcome at the woods edge ceremony, in order to cement mutual obligations through empathy and assist all to meet with "good minds," which are arenas where "condolence" would seem an odd translation in European traditions.

More fundamentally, the personal and the political are united in the core values of the Kayaneren'kó:wa, which is known as the Great Law of Peace. The message of peace that Deganawida brought to Hiawatha to help him overcome his grief is the same that the two men, with clan mother Jigonsaseh, used to convince the warring nations to come together into the metaphoric longhouse of the Haudenosaunee confederacy. The message was that thinking with a good mind and with reason would bring peace and overcome the practice of ruling by fear. The ways to achieve this were remembered in the Kayaneren'kó:wa as the principles of peace, power (or civil authority), and righteousness. ${ }^{123}$ The Kayaneren 'kó: wa is as holistic as the condolence is versatile, because although it is seen as a constitution or a treatise on international law and the federation of Haudnosaunee nations, relations between nations are understood to form an integral part of living well, which is the real focus of the Great Law. ${ }^{124}$ Both the personal and the political (to the extent that the distinction can be drawn) are understood with respect to their place in the natural order. Alternative translations for Kayaneren'kó:wa are "the big harmony,", 25 "the great good way," "26 or "the way of living most nicely together.",27

The links between interpersonal reconciliation and political reconciliation, so thick in the condolence ceremony, are unclear in the context of the TRC. It may be, as Marlene Brant Castellano suggests, simply that the former evolves into the latter when there is "awareness and acknowledgement experienced at a thousand points of encounter between Aboriginal and non-Aboriginal people, so that the need for change

120 Brian Deer, "The Iroquois Condolence" (2005) 159 Ecumenism 4 at 4.

121 Teyowisonte Thomas Deer, personal communication (February 2013).

${ }^{122}$ Mark Abley, Spoken Here: Travels among Threatened Languages (Toronto: Random House, 2003) at 171.

${ }^{123}$ Dawn Martin-Hill et al, "Jidwadoh: Let’s Become Again" (2008) 5:2 Pimatisiwin 55 at 63. See also Taiaiake Alfred, Peace, Power, Righteousness: An Indigenous Manifesto (Toronto: Oxford University Press, 1999).

124 David Bedford \& Thom Workman, "The Great Law of Peace: Alternative Inter-Nation(al) Practices" (1997) 22:1 Alternatives 87 at 88 .

${ }^{125}$ Alfred, supra note 123 at 102.

126 Brian Deer, personal communication (May 2010).

${ }^{127}$ Patricia Monture-Okanee, "Thinking about Aboriginal Justice: Myths and Revolution" in Richard Gosse James Youngblood Henderson \& Roger Carter, eds, Continuing Poundmaker and Riel's Quest: Presentations Made at a Conference on Aboriginal Peoples and Justice (Saskatoon: Purich Publishing, 1994) at 227. 
and the promise of a new relationship ripples through networks of families, communities, and nations." "128 Others argue that interpersonal and political reconciliation are distinct and ought to remain separate. Writing on South Africa, Ari Kohen, for one, considers that reconciliation between victim and offender is a tall order but that it is not necessary for reconciliation between groups in society. What is necessary at the personal level is what he labels as forgiveness, defined as "letting go of the power the offense and the offender have over a person." 129 Personal forgiveness is necessary to broaden political reconciliation because, as Trudy Govier puts it, "people cannot come together in a lasting way and co-operate as they will need to in a jointly run society if they remain angry, vengeful, suspicious, and insecure." ${ }^{130}$ It seems that the healthful peace of the condolence ceremony and the Great Law similarly bridges the distance between the individual healing of those (on both sides) traumatized by colonization and the political reconciliation of abstract entities like government or community. Political peace is dependent on personal peace.

\section{Metaphor and the Numinous: Living Language and Ecological Law}

However, there is also a spiritual significance of the ceremony without which it is difficult to understand. The reciprocal obligation to perform the ritual is urgent because of the need to protect both individuals and Haudenosaunee society from malignant forces associated with death. ${ }^{131}$ An alternative name for the condolence is Hai Hai, ${ }^{132}$ a sound made in the roll call of chiefs (journeying on the trail) that William Beauchamp identifies as the cry of departed souls and which, if omitted, would displease the souls and cause them to send disease. ${ }^{133}$ Replacing a departed chief or clan member through the requickening is a way of assuaging the power of death to disrupt the political and social order. Many aspects of the condolence rites in the Great Law of Peace speak to a need to respect the boundedness of humans within both an earthly and a transcendent realm. It is our location in the natural order - Creation - that provides guidance as to what is politically appropriate. ${ }^{134}$ However, and in contrast to a modern understanding of "reality," Creation comprehends everything that is, was, and will be, including stories, dreams, and the product of what in English we call imagination. It is tempting for modern cultures to bracket out the spiritual aspect and read the condolence in terms of its functions as a ritual of relation. But, as Haudenosaunee authors Joe Sheridan and Dan Longboat argue so powerfully, "old growth" Indigenous cultures in North America have evolved symbiotically with the land, its animals, its geology, and its climate, which provide the metaphors for knowing. If Indigenous mythology is "how Creation thinks on

${ }^{128}$ Marlene Brant Castellano, "A Holistic Approach to Reconciliation: Insights from Research of the Aboriginal Healing Foundation" in Marlene Brant Castellano, Linda Archibald, and Mike DeGagné, eds, From Truth to Reconciliation: Transforming the Legacy of Residential Schools (Ottawa: Aboriginal Healing Foundation, 2008).

${ }^{129}$ Ari Kohen, "The Personal and the Political: Forgiveness and Reconciliation in Restorative Justice" (2009) 12:3 Critical Review of International Social and Political Philosophy 399.

${ }^{130}$ Trudy Govier, Forgiveness and Revenge (London: Routledge, 2002) at 144.

${ }^{131}$ Foley, supra note 116 at 25.

132 William Fenton, "The Roll Call of the Iroquois Chiefs: A Study of a Mnemonic Cane from Six Nations Reserve" (1950) 111:15 Smithsonian Miscellaneous Collections 1 at 47.

133 William Beauchamp, "Civil, Religious and Mourning Councils and Adoption Ceremonies of the New York Indians" (1907) 113 New York State Museum Bulletin 341 at 352.

${ }^{134}$ Bedford \& Workman, supra note 124 at 96. 
this continent," $" 135$ then the imaginative dimensions of the condolence and other ceremonies are "the physical/spiritual expressions of Creation's legitimate interconnected ecologies, whether those ecologies are stories, watersheds, or minds." 136

Thus, when we translate Kayaneren 'kó:wa as "law" in a conventional English sense and then look to condolence ceremonies for the practical ways they carry this law into effect, what we miss are the numinous or transcendental aspects. One way to welcome them is to look at the performative or aesthetic aspects of the condolence and not just its content. For instance, while the Kayaneren 'kó:wa can be read as containing prescriptions, prohibitions, and obligations, a crucial aspect of its style is the way that metaphor is used as a discursive method in Haudenosaunee tradition. ${ }^{137}$ An interesting example is given by US historian Michael Pomedli who compares the language of official versions of eighteenth-century treaties between the English and the Haudenosaunee and the transcripts of their negotiations, whose proceedings were adapted from the condolence. The official treaties purport to convey the content of an agreement in a legal style that is largely familiar today - impersonal, devoid of obvious imagery, built on the differentiation between categories of people, events, and things. The English procedures display a sequential logic of agreement, assent, authorization, and publication that culminate in a distinct product, a binding contract. ${ }^{138}$

By contrast, and even in translation, the condolence orations are overflowing with metaphor: casting the weapons of war into a pit of oblivion; planting the tree of peace; the central fire; adding rafters to the longhouse; extending arms; and freeing paths of obstructions. ${ }^{139}$ The imagery is reinforced through performative and ceremonial acts like lighting a fire, grasping arms, exchanging gifts or strings of wampum, or smoking a pipe. There is layer upon layer of imagery that refers back to other ceremonies and older stories. While the style might seem chaotic to the uninitiated, the metaphors "collide then cycle back out into new associational meanings" since this form of discourse is associational rather than linear. ${ }^{140}$ The "tensive language" used in condolence (language that has living vitality), ${ }^{141}$ Pomedli argues, is not there to disseminate information for its own sake but, rather, to invite others to participate in a particular way of seeing and feeling, to engage "the self and society within the invisible." 142 It is often observed that Indigenous understandings of the historic treaties as an ongoing process, a relationship that needed tending as the image of "polishing the chain" evokes, stood in stark contrast to European understandings of them as a reified legal object, a "contract." The preceding discussion suggests that there

\footnotetext{
135 Joe Sheridan \& Roronhiakewen "'He Clears the Sky' Dan Longboat, The Haudenosaunee Imagination and the Ecology of the Sacred" (2006) 9:4 Space \& Culture 365 at 368-371, 376.

136 Ibid at 370 .

137 George S. Snyderman, “The Functions of Wampum'; Proceedings of the American Philosophical Society” (1954) 98:6 American Philosophical Society 469.

138 Pomedli, supra note 118 at 331.

139 See Willian N Fenton, The Great Law and the Longhouse: A Political History of the Iroquois Confederacy (Norman, OK: University of Oklahoma Press, 1998) at 308-309. In Haudenosaunee languages, which are highly descriptive, the images are even more vivid.

140 Barbara A Mann, “The Lynx in Time: Haudenosaunee Women's Traditions and History” (1997) 21:3 American Indian Q 423 at 429.

141 See Paul Ricoeur, The Rule of Metaphor: The Creation of Meaning in Language, translated by Robert Czerny, Kathleen McLaughlin and John Costello, 3d ed (London: Routledge, 2003) at 295-296.

142 Pomedli, supra note 118 at 329.
} 
is not just a different "principle" being applied but also a different ontology of "time, mind, spirit, and place." 143

Translating ka'nikonhrakétsko/condolence as a reconciliation ritual on the face of it highlights the psychophysical aspects of healing that are needed for peaceful living in community, but the broader forms and contexts for the condolence ceremonies point to ways in which European secular traditions do not usually link the different scales and modes of human existence. There is historic precedent for the adoption of this ceremony - via the two-row wampum - in relating to newcomers to Canada, even in the face of great cultural differences. That contemporary Haudenosaunee almost universally locate their relationship with the state in these terms makes it a particularly apt model for thinking through reconciliation today. Where the ceremony is translated purely in functional terms, though, an important lesson is missed. As with msit no 'kmaq, the protocols of condolence are an acknowledgement and performance of the place of human beings in a "spiritual ecology." That is, the fact that both spirit and imagination are essential to the work of condolence speaks to an "enchanted" world in which language is alive and law grows with its environment, not one in which law is reduced to a rational, mechanistic, and instrumental artifact as in the modernist European tradition. ${ }^{144}$

\section{Gitxsan: Niid'nt (Guests at a Feast)}

The last example presented here concerns the notion of "witnessing," which featured in the way in which community members, both Indigenous and non-Indigenous, were invited to be involved in the TRC's processes and, especially, in the public performance of survivor testimonies. Referring to witnessing as an Aboriginal principle that varies among First Nation, Inuit, and Metis peoples, the explanation of the role of honorary witnesses in the TRC report notes two main reasons for the use of witnesses in Indigenous oral cultures. The first is for the "recording" of major events in individual memories that can later be shared. The second is the importance of conducting business, building, and maintaining relationships in person and face to face in a way that validates the event. ${ }^{145}$ If we wish to understand in more detail the place of witnessing in reconciliation and the maintenance of lawful peace from Indigenous perspectives, the feast halls of Northwest coast peoples offer well-documented and highly structured examples. What they teach us, as I will show below, is that the role of witnesses is not as a passive observer, but, rather, as for a contract or a formal marriage, is an important element in creating legality. Further, embedded as they are in an oral and small-scale culture, witnesses preserve for posterity a specific individual view of events; relying on multiple witnesses results in honouring the possibility of divergent perspectives. In a cross-cultural context, the ability to hear the experiential truth of different parties may be crucial to understanding the nature of colonialism and engaging in reconciliation.

143 Sheridan \& Longboat, supra note 135 at 375.

144 On imagination in legal theory, see Mark Antaki, “The Turn to Imagination in Legal Theory: The Re-Enchantment of the World?" (2012) 23:1 Law \& Critique 1; on enchantment as the inherent meaningfulness of the world, see Eduardo Kohn, How Forests Think: Toward an Anthropology beyond the Human (Berkeley: University of California Press, 2013) at 72, 89-92.

145 TRC, "Reconciliation: Towards a New Relationship: Honourary Witness" (15 October 2009), online:

$<$ http://www.trc.ca/websites/reconciliation/index.php? $\mathrm{p}=331>$. 


\section{The Feast Hall}

The oral histories of Northwest coast peoples such as the Gitxsan and their neighbours the Wet'suwet'en, the Nisga'a, and the Tsimshian, tell of using feasts to make peace with hostile neighbours and to demonstrate ownership over territories in dispute. Feasts ( $y u k w$ in Gitxsan) continue to be the place where the social, legal, and political business of these communities takes place - for example, funerals and the succession of chiefly titles, the transfer or declaration of rights to territory, the marking of births and other life events and achievements, the formalization of marriage and trade alliances, the settlement of disputes, or the restoration of status of someone shamed by a damaging event. ${ }^{146}$ Although there are many different kinds of feasts specific to these different purposes, the basic form of the institution is literally a feast hosted by the lineage or "House" (wilp in Gitxsan) wishing to conduct business, assisted by related lineages, with members of opposing lineages as guests. ${ }^{147}$

Proceedings may involve formally seating guests according to their ritual name and rank; giving gifts, paying compensation or repaying debts; speeches that give accounts of the speakers' territory and how its association with the lineage and with specific ceremonial robes, songs, and crests came about, often told via formal oral histories (adaawk in Gitxsan); serving a meal for which the providence of the ingredients in the territories of the hosts confirms ownership of the territory as well as its bounty; or performances or representations of events that demonstrate the spiritual powers of the host chief. Feasts are part of a larger system of compensation and legal redress, known in Gitxsan as xsiisxw, in which one house will give wealth, titles, crests, or territories to repay an offence committed against another house. ${ }^{148}$ More generally, feasts are part of what anthropologists know as kin-based gift economies in which giving creates patterns of mutual endebtedness that calibrate social hierarchy and power, but in which what is valued is generosity, altruism, and kindness. ${ }^{149}$

\section{Witnesses and the Making of Law}

The Gitxsan term for invited guests - niidn't - translates as "the ones who approve." 150 This clearly takes their role beyond the passive one of merely recording events in memory - being the "keepers of history," as the TRC puts it - to one of legitimation, validation, or formal recognition of the claims being presented by the host simgigyat (chiefs) - hence, the importance of the public nature of feasting. ${ }^{151}$ The approval of the House on the father's side in the opposite clan (nii 'dill) carries the most weight, and they

${ }^{146}$ For basic description of the $y u k w$, see Richard Overstall, "Encountering the Spirit of the Land: 'Property' in a KinshipBased Legal Order" in John McLaren, AR Buck \& Nancy Wright, eds, Despotic Dominions: Property Rights in British Settler Societies (Vancouver: UBC Press, 2004) 22 at 28-30; Susan Marsden, "Northwest Coast Adawx Study" in Catherine Bell \& Val Napoleon, eds, First Nations Cultural Heritage and Law: Case Studies, Voices, and Perspectives (Vancouver: UBC Press, 2008); Richard Daly, Our Box Was Full: An Ethnography for the Delgamuukw Plaintiffs (Vancouver: UBC Press, 2005) at 81-94; John Adams, The Gitksan Potlatch: Population Flux, Resource Ownership and Reciprocity (Toronto: Holt, Rinehart and Winston Canada, 1973) at 1-15.

147 Overstall, ibid at 28.

148 Ibid at 40.

${ }^{149}$ See, eg, Marcel Mauss, The Gift: The Form and Reason for Exchange in Archaic Societies, translated by W.D. Halls (London: Routledge, 1990).

${ }^{150}$ Ibid at 35.

${ }^{151}$ H.G. Barnett, "The Nature of the Potlatch" (1938) 40:3 American Anthropologist Journal 349 at 351-352. 
have a special responsibility and authority related to witnessing. ${ }^{152}$ For example, if a mistake is made, as in the mis-description of territorial boundaries discussed by Val Napoleon in her presentation of Gitxsan law, the nii 'dill have a legal duty to correct it for the record. ${ }^{153}$ They may also be called upon to intervene in a future dispute or attest to the truth of the House's claims. Because of the small-scale and face-to-face nature of Gitxsan legal interactions, statements of knowledge are always associated with a specific speaker, ${ }^{154}$ whose claim to truth will depend on having received a story from a reliable source. Antonia Mills notes that Wet'suet'en sources sometimes show two different accounts that can be traced back to eyewitnesses of the event, but that they "consider it a point of accuracy to retain separate and divergent accounts." 155

In anthropological terms, feasts are "ontogenic." 156 They do not just tell stories and describe rights over territories, the power of chiefs or the reciprocal relations of gift giving and endebtedness between clans and houses, but they also enact them or bring them into being. Thus, feasts share the formal qualities of parliamentary law-making in the Westminster system, where it is the internal significance of symbolic acts of assent, in terms of the authority they represent, that turns words on a page into law. ${ }^{157}$ In speech act theory, these are "performative" speech acts that actually do, rather than simply describe, law. In these terms, witnesses are part of the conditions required to make these speech acts effective or "felicitous." 158 In the feast halls, then, witnesses are at the heart of making Gitxsan law legal. ${ }^{159}$

\section{Cross-Cultural Adaptation of the Feast: Lessons for Reconciliation}

Like the ecumenical extension of the condolence ceremony by the Haudenosaunee, elements of the feast have in the past been adapted by the Gitxsan to extend their understanding of legal principles to nonGitxsan people. For example, in the early days of the colony of British Columbia, trespass or breaches of protocol according to Gitxsan law by settlers sometimes led chiefs to attempt to engage colonial authorities in feasting or to extract compensation (while the latter were attempting, at cross purposes, to install the "rule of law" as they understood it). ${ }^{160}$ In the Delgamuukw trial, the Gitxsan and Wet'suet'en told their adaawk and kungax as evidence of their ownership of, and jurisdiction over, their traditional territories and, in doing so, consciously adopted means of proof that would operate in the feast hall. ${ }^{161}$ More recently, as recounted by former IRS claims resolution manager Paulette Regan, the Gitxsan chose to use the feast to repatriate IRS students and as the forum in which the federal government and the United Church would

\footnotetext{
152 Overstall, supra note 148 at 35.

153 Val Napoleon, Ayook: Gitxsan Legal Order, Law and Legal Theory (PhD thesis, University of Victoria, 2009) at 128130.

154 Overstall, supra note 146 at 35

155 Antonia Mills, Eagle Down Is Our Law: Witsuit'en Law, Feasts and Land Claims (Vancouver: UBC Press, 1994 ) at 75.

156 Daly, supra note 146 at 57.

157 See Hans Kelson's account of what makes law "law" in Western legal traditions. "The Pure Theory of Law" (1934) 50 Law Q Rev 474 at 477.

158 Marianne Constable, Our Word Is Our Bond: How Legal Speech Acts (Stanford: Stanford University Press, 2014) at 23, 85.

159 "The public announcement of the fact and tacit recognition of the fact by the guest group, so to speak, legalized the claim." Philip Drucker, Cultures of the North Pacific Coast (Scranton, PA: Chandler Publishing Company, 1965$)$ at 56.

160 RM Galois, "The Burning of Kitsegukla, 1872” (1992) 94 BC Studies 59.

161 Regan, supra note 4 at 166.
} 
offer their apologies for residential schools. ${ }^{162}$ In accordance with Gitxsan understandings of how wrongdoers make restitution, it was the representatives of these institutions, Regan among them, who hosted the feast. In extending roles to non-Gitxsan participants, Regan argues, the Gitxsan engaged in "a powerful act of diplomacy" that performatively shifted power from the government officials, who had to become students and subjects of Gitxsan law in order to fulfil their roles, to Gitxsan leaders, who were now the authoritative experts. It also demonstrated the resilience and adaptability of Gitxsan legal traditions in the face of new circumstances.

It goes without saying that the complex structures and protocols of the feast hall could not simply "apply" to TRC hearings or to witnessing. They are deeply embedded in Gitxsan social structures, laws, and territories, and adapting them remains the prerogative of the Gitxsan. However, if witnessing within the TRC is a way to embody "Aboriginal principles," then there must be a way for feasts to teach us in a more generalizable way. The first lesson might be that witnessing is part of Indigenous legal orders and not simply a personal or psycho-social act. Witnessing is part of a public performance of lawfulness. In the TRC, the survivors' statements are a testament not just to the facts of what happened to them in residential school but also, like the claims presented by the simgigyat, to their understandings of harm, of right and wrong, and of restitution and redress - in short, to a legal sensibility that may be informed by their Indigenous traditions, by their non-Indigenous education, or by a mixture of both. This might explain, as Ronald Niezen notes, that some witness statements stray from issues strictly related to residential schools so as to air other grievances that the opportunity of having the microphone calls forth. ${ }^{163}$ In this way, TRC witnesses are being asked to attest to the lawfulness of survivors' claims in a way that is open to Indigenous law and a multitude of senses of injustice.

However, unlike niidn't, whose authority to approve is based on accumulated experiences with shared Gitxsan law, many TRC witnesses will lack a common background with those testifying. Non-Indigenous witnesses looking to approve based on their own understanding risk replicating the colonial configuration that reconciliation processes ought to eschew. For US philosopher Kelly Oliver, this is the conundrum with recognition as a response to injustice. As she puts the issue, how is it possible to recognize something that is unfamiliar or unknown? How is it possible to recognize the other except in terms of the self? ${ }^{164}$ One part of her answer points to a distinction between being an eyewitness to events and "bearing witness" to something that cannot be seen or known, something beyond recognition. As Oliver puts it, "the truth of trauma and victimization is lost even in the most astounding statistics. ... all experiences of objectification and subordination are the inarticulatable experiences of inhumanity that can only be repeated in testimony or performed in various ways but never fully reported in historical facts." ${ }^{.165}$ Witnessing in this second

162 Ibid at 193-212.

163 Ronald Niezen, Truth and Indignation: Canada's Truth and Reconciliation Commission on Indian Residential Schools (Toronto: University of Toronto Press, 2013) at 99-100.

164 Kelly Oliver, Witnessing: Beyond Recognition (Minneapolis: University of Minnesota Press, 2001) at 2. One solution comes through Charles Taylor's work on dialog as a means to shift our horizons of judgment, so that questions of value or significance only come about after real engagement with other people's ways of thinking. Oliver's critique is that this approach is articulated from the position of a sovereign subject who chooses to engage with otherness and that it presumes understanding based only in intellect rather than affect: 44-46.

165 Ibid at 92. 
sense goes beyond the testimony of empirical or historical fact in IRS experiences and gets at the experiential truth both of the nature of colonialism and of Indigenous peoples' collective will to survive .

For Regan, the way Indigenous peoples use storytelling and ceremony as a pedagogical practice involving all of the senses resonates with the experiential aspects of witnessing just described. For example, Coast Salish scholar Robina Thomas describes an obligation among her people to treat stories respectfully with a Hul'qumi'num word " $u y$ 'skwuluwun (a good mind and a good heart) and relates it to the obligation undertaken by witnesses to events in the Coast Salish "Big House."166 Non-Indigenous witnesses may not be trained in this way; they may miss the protocols for listening that would make their responses a way to honour Indigenous traditions. However, what all witnesses do have is their own responses, and even when these spring, sometimes unbidden, from ignorance and prejudice - perhaps especially when they spring from ignorance and prejudice - they act as important signposts for the symptoms of colonialism. In a crucial point about the nature of ethical witnessing for settlers, Regan hones in on these instinctive responses as being particularly telling of where the unsettling work of decolonization may lie. ${ }^{167}$ So a second lesson lies in the ethical responsibility to bear witness to the experiential truths - both of the teller and the listener - that come out of the process of witnessing.

A third lesson lies in what political philosopher Natalie Oman identifies in the feasts as a model of peacemaking through intercultural understanding. ${ }^{168}$ The use of stories (adaawk), traceable back to firstperson experiences, as the vehicle for making and responding to claims means that there will sometimes be divergent accounts of the same events because they were perceived differently, as we heard above. Consequently, Gitxsan epistemology embraces, rather than eschews, the refractory nature of complex events. Oman claims that "[b]y exposing the witnesses to diverse perspectives on the same incidents, this telling [of diverging accounts] is designed to inspire reflection on the varieties of distance that separate each participant and the multiplicity of their truths." 169 This multiplicity is something that seems instinctively promoted by the TRC, which, for example, invites survivors to "tell your truth." $"$ By formalizing diversity in the adaawk, the feast hall preserves the inevitability of alternative perspectives and offers participants permanent opportunities to realize the limitations of their own understandings. This may well be a crucial prelude to the possibility of reconciliation across radical differences.

\section{CONCLUSION}

One way in which the TRC has arguably contributed to an "overall holistic and comprehensive response to the Indian Residential School legacy" is by respecting Indigenous legal traditions, since these, via attacks on language, culture, and sovereignty, were among the casualties of residential schools. ${ }^{171}$ The emphasis on witnessing during truth and reconciliation events as an Aboriginal principle is the most

\footnotetext{
${ }^{166}$ Cited in Regan, supra note 4 at 189.

167 Oliver, supra note 164 at 191.

168 Natalie Oman, "Paths to Intercultural Understanding: Feasting, Shared Horizons and Unforced Consensus" in Catherine Bell \& David Kahane, eds, Intercultural Dispute Resolution in Aboriginal Contexts (Vancouver: UBC Press, 2004$) 70$.

169 Ibid at 83 .

170 Although note Niezen's argument that the processes of the TRC that encouraged and affirmed certain narratives, together with actual or anticipated audience responses, shaped the kinds of truths that were aired. Niezen, supra note 163 at 20.

171 Indian Residential Schools Agreement, supra note 3.
} 
explicit example, but the use of prayer, the sacred fire, drumming, and talking circles in the proceedings are some other gestures to Indigenous traditions. Together with the general "victim-centred approach," the inclusion of Indigenous traditions "enacts a form of ongoing symbolic reversal of the power relations and colonial knowledge assumptions that were embodied in the schools and that continue to be woven into Canadian institutions and society today." ${ }^{172}$ The recognition of Indigenous traditions in this way is thus not just a direct, converse, response to attempts to quash them but can also potentially address, and be transformative of, broader colonial structures and mindsets that were and are responsible for injustices against Indigenous peoples.

However, such symbolic practices have little chance of altering colonial knowledge assumptions unless, first, they are understood as part of Indigenous legal orders and, second, there is a conscious attempt to engage their significance for colonial ways of knowing. The narrow mandate of the TRC - its focus on survivor experiences and perspectives and impotence with respect to investigating wrongdoing or identifying offenders - makes it more difficult for such soul-searching to have a prominent formal place. And a general ignorance makes it all too easy to read Indigenous ceremonies as decorations rather than instantiations of Indigenous law. There remains, nevertheless, a "decolonizing and ultimately liberatory potential" in the work of the TRC and the ongoing discourses and practices that it may inspire. ${ }^{173}$

This article has set out one possible method for engaging with Indigenous traditions in a way that goes beyond lip service and beyond the limitations of superficial forms of recognition in which equivalence is too quickly assumed. By paying attention to the ways that Indigenous principles and practices are embedded in a network of ideas about the world, a picture of a whole "legal sensibility" emerges that, through comparison, shows up the dominant legal sensibility as one alternative among many. Although the TRC has had no mandate to hold persons or institutions to account, each individual Canadian needs to be challenged to take on the ethical responsibility of being accountable for their ways of thinking.

The three examples worked through in the third part of this article point to some intellectual and practical resources for rethinking and redoing reconciliation. The circle in the TRC logo symbolizes inclusiveness, interconnection between people, and renewal. Investigating the philosophies of Algonquian-speaking nations, I have highlighted how European understandings of circles as an abstract, linear geometrical entity might bring negative associations of repetition or stasis and suggest the necessity for thinking through the kinds of relationships that are envisaged by the inclusivity of reconciliation processes. The Haudenosaunee condolence ceremonies provide a way of connecting the interpersonal and political aspects of reconciliation through the holistic approach of the Great Law of Peace to "living well." Finally, the role of witnesses in the Gitxsan feast halls underscores the role of public performance in establishing the legitimacy of claims of law and justice rather than taking witnesses as passive recorders of events.

\footnotetext{
172 James, supra note 99 at 2-3.

173 Regan, supra note 4 at 216.
} 